\title{
Aortic Arch Thrombosis Associated with Fetal Cytomegalovirus Viremia
}

\author{
Elif Gul Yapar Eyi ${ }^{1} \quad$ Nahide Altuğ ${ }^{2}$ \\ 1 Perinatology Subdivision, Zekai Tahir Burak Women's Health \\ Education and Research Hospital, Ankara, Turkey \\ 2 Pediatric Cardiology, Zekai Tahir Burak Women's Health Education \\ and Research Hospital, Ankara, Turkey
}

\begin{abstract}
Address for correspondence Elif Gul Yapar Eyi, Perinatology Subdivision, Zekai Tahir Burak, Women's Health Education and Research Hospital, Talatpasa Boulevard, Ankara 06230, Turkey (e-mail: elifgulyapar@gmail.com).
\end{abstract}

Am J Perinatol Rep 2018;9:e23-e26.

\begin{abstract}
Keywords

- thrombosis

- cytomegalovirus

- aortic arcus

- viremia

- fetus

Cytomegalovirus(CMV) associated thrombosis has been reported sporadically in the medical literature; however, its antenatal scenario has not been documented. We herein present the antenatal, Doppler's ultrasound and magnetic resonance angiographic features of thrombosis in the aortic arch showing extension toward the medial lumen of the brachiocephalic trunk with critical occlusion of the left common carotid artery and left subclavian artery in a term fetus to raise obstetricians'/ neonatologists' pediatric cardiologists' awareness for the association between CMV viremia and intrauterine thrombosis that caused cerebral injury, neurodevelopmental impairment, and permanent sequela.
\end{abstract}

The detection of a fast heart rate greater than 180 beats per minute (bpm) in a term fetus should be considered as a medical emergency because it carries a significant risk of hemodynamic compromise, heart failure, morbidity, and even mortality. Identifying the etiology together with its hemodynamic impact is important because both the management and prognosis differ among the various disorders. We herein present the clinical and laboratory findings of thrombosis in the aortic arch in a term fetus presenting with tachycardia in whom congenital cytomegalovirus(CMV) infection was detected in the early neonatal period.

\section{Case}

A 38 -year-old primigravid woman at $38^{6 / 7}$ weeks of gestation was hospitalized as detection of a fetal heart rate exceeding $200 \mathrm{bpm}$ on antepartum cardiotocograph. Four chamber view and the outflow tracts appeared normal. Echocardiography revealed severe tricuspid regurgitation $(3.2 \mathrm{~cm} / \mathrm{sec})$ and poor myocardial contraction. Maternal past medical history revealed Raynaud's phenomenon. Familial and antenatal follow-up was uneventful. There was no exposure to any drug or medication during pregnancy. She was taken to emergent cesarean section. A female infant weighing $3,720 \mathrm{~g} / 52 \mathrm{~cm}$ (head circumference: $37 \mathrm{~cm}$ ) with 7 and 9
Apgar's scores at 1 and 5 minutes were delivered. Cyanosis unresponsive to oxygen therapy was present. Radiological, hematological, and biochemical parameters were shown in -Table 1 and -Table 2. Echocardiography depicted the dilatation of the heart. There was an echogenic mass measuring $10 \times 5 \mathrm{~mm}$ in the aortic arch restricting the antegrade flow to the descending aorta. Thrombogenic mass was also detected in the left interatrial septum. Systolic functions decreased (-Videos $\mathbf{1}$ and 2). Magnetic resonance imaging (MRI) angiography depicted that thrombosis in the aortic arch was showing extension toward the medial lumen of the brachiocephalic trunk with critical occlusion of the left common carotid artery and left subclavian artery (-Fig. 1A-E). Because of the potential organ and life-threatening location of the thrombus, recombinant human tissue type plasminogen activator (t-PA: $0.2 \mathrm{mg} / \mathrm{kg} /$ hour) for 6 hours, prostaglandin E1 $(0.1 \mathrm{mg} / \mathrm{kg} /$ minute), and inotropic agent (Dopamine $5 \mathrm{mg} / \mathrm{kg} /$ minute) were infused. Over the subsequent 24 hours, echocardiography showed resolution of the thrombus. The t-PA and prostaglandin were discontinued. Intracranial hemorrhage was reported on the cranial ultrasonography. Convulsions started. Anticonvulsant agents were administered. Anticoagulant therapy with enoxaparin: $2 \times 3.62 \mathrm{mg}$ was initiated on the fourth day. Hereditary and acquired thrombophilia tests revealed no pathology. received

September 6, 2018

accepted

September 11, 2018
DOI https://doi.org/

10.1055/s-0038-1675631. ISSN 2157-6998.
Copyright $\odot 2019$ by Thieme Medical Publishers, Inc., 333 Seventh Avenue, New York, NY 10001, USA. Tel: +1(212) 584-4662.
License terms

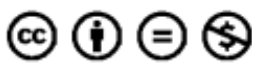


Table 1 Symptoms and radiological findings

\begin{tabular}{|c|c|c|c|}
\hline Symptoms & Immediately after birth & 24-48 hour after birth & Following days \\
\hline $\begin{array}{l}\text { Echocardiography } \\
\text { (-Videos } 1 \text { and } 2 \text { ) }\end{array}$ & $\begin{array}{l}\text { Tachycardia, dyspnea, hyperventilation } \\
\text { Cyanosis, reduced brachial pulse, reduced femoral } \\
\text { pulse } \\
\text { - } 10.0 \times 3.5 \mathrm{~mm} \text { thrombus in the aortic arch } \\
\text { - Thrombus in the atrial septum } \\
\text { - Mitral regurgitation: } 3.5 \mathrm{~m} / \mathrm{s} \\
\text { - Tricuspid regurgitation: } 3.2 \mathrm{~m} / \mathrm{s} \\
\text { - Ejection fraction } 56 \% \\
\text { - Left ventricular fractional shortening } 27 \%\end{array}$ & $\begin{array}{l}\text { Convulsions/intubated } \\
\text { No thrombus in the } \\
\text { aortic arch } \\
\text { Decrease in the dimen- } \\
\text { sion of the thrombosis } \\
\text { in the atrial septum }\end{array}$ & Extubated on day 11 \\
\hline Cranial ultrasound & $\begin{array}{l}\text { - Atrial width: } 11 \mathrm{~mm} \text { bilateral encephalomalacia } \\
\text { near the right lateral ventricle measuring } \\
8 \times 4 \mathrm{~mm} \text { and near the left lateral ventricle } \\
\text { measuring } 5 \times 7 \mathrm{~mm}\end{array}$ & & $\begin{array}{l}\text { Bilateral encephaloma- } \\
\text { lacia near the right lat- } \\
\text { eral ventricle measuring } \\
18 \times 20 \mathrm{~mm} \text {, near the } \\
\text { left lateral ventricle } \\
\text { measuring } 15 \times 7 \mathrm{~mm}\end{array}$ \\
\hline $\begin{array}{l}\text { Cranial computed } \\
\text { tomography }\end{array}$ & $\begin{array}{l}\text { - Left frontoparietal and right parietal subarach- } \\
\text { noid hemorrhage } \\
\text { - Intraparenchymal hemorrhage } \\
\text { - Brain edema } \\
\text { - The diminished contour of the hemispheric } \\
\text { sulcus }\end{array}$ & & \\
\hline $\begin{array}{l}\text { Cranial magnetic } \\
\text { resonance } \\
\text { angiography } \\
\text { (-Fig. 1A-E) }\end{array}$ & $\begin{array}{l}\text { - Thrombosis in the aortic arch extending toward } \\
\text { the medial lumen of the brachiocephalic trunk } \\
\text { with critical occlusion of the left common car- } \\
\text { otid artery and left subclavian artery } \\
\text { - Loss of calibers in the right internal carotid artery } \\
\text { - There is no apparent flow in the right thin } \\
\text { anterior cerebral artery and midcerebral artery } \\
\text { - Retrograde and collateral circulation, which is } \\
\text { thought to be coming from external carotid } \\
\text { artery } \\
\text { - Swelling of the basal ganglia and leukomalacia }\end{array}$ & & \\
\hline
\end{tabular}

Heterozygote mutation in the MTHFR A1298C was detected in the newborn (-Table 2 ).

\section{Video 1}

Axial view of the transverse aorta depicting the outflow tract of the brachiocephalic trunk, the left common carotid artery and the subclavian artery. Aortic coartactation pattern is seen with color Doppler. Online content including video sequences viewable at: www.thieme-connect.com/products/ejournals/html/ 10.1055/s-0038-1675631.

\section{Video 2}

One thrombosis in the aortic arch measuring $10.0 \times 3.5$ $\mathrm{mm}$ is present impairing the blood flow to critical levels. Online content including video sequences viewable at: www.thieme-connect.com/products/ ejournals/html/10.1055/s-0038-1675631.
$1.77 \times 107$ copies/mLCMV DNA(deoxyribonucleic acid) was detected in serum samples of the neonate by polymerase chain reaction (PCR). Mother was CMV IgM (immunoglobulin $\mathrm{M}$ ) seronegative. She was CMV IgG seropositive with high avidity. No virus was detected in breast milk ( - Table 2 ). Baby received Ganciclovir infusion (18 mg twice daily) due to the acute viremia in the second week. Electroencephalography depicted severe abnormality. No sign of chorioretinitis was detected in the eye examination. She was discharged home on enoxaparin and anticonvulsant therapy on the 55th day after birth.

\section{Discussion}

Arterial thrombosis is much less common than venous thrombosis. ${ }^{1}$ The symptomatic neonatal arterial thromboembolic disease has been reported to be between 2.5 to $5.1 / 10,000$ live births ${ }^{2,3}$ and 2/79 (2.5\%) of the cases were documented as aortic thrombosis. ${ }^{3}$ Mortality has been quoted as high as $33 \%$ in infants with aortic thrombosis. ${ }^{3,4}$ Among the several reports on the thrombosis of the aorta during the neonatal period, ${ }^{1-6}$ aortic arch thrombosis associated with CMV infection has been reported twice ${ }^{5,6}$ and antenatal findings have not been published previously.

Natural history of CMV infections during pregnancy is complex and not fully understood. A pregnant woman who is 
Table 2 Laboratory findings of the newborn and the mother

\begin{tabular}{|c|c|c|}
\hline & Newborn & Mother \\
\hline Blood count (at birth) & $\begin{array}{l}\text { Hemoglobin: } 16 \mathrm{~g} / \mathrm{dL} \\
\text { Hematocrit: } 52.1 \% \\
\text { WBC: } 18,600 / \mathrm{mm}^{3} \\
\text { Platelets: } 143,000 / \mathrm{mm}^{3}\end{array}$ & \\
\hline Coagulation profile (at birth) & $\begin{array}{l}\text { PT: } 15 \mathrm{~s} \\
\text { aPTT: } 42 \mathrm{~s} \\
\text { INR: } 1.44 \\
\text { Fibrinogen: } 141 \mathrm{mg} / \mathrm{dL}\end{array}$ & \\
\hline Biochemical (at birth) & $\begin{array}{l}\text { BUN: } 13 \mathrm{mg} / \mathrm{dL} \\
\text { Creatinine: } 0.34 \mathrm{mg} / \mathrm{dL} \\
\text { ALT: } 33 \mathrm{mg} / \mathrm{dL} \\
\text { AST: } 42 \mathrm{mg} / \mathrm{dL} \\
\mathrm{Na}: 141 \mathrm{mEq} / \mathrm{dL} \\
\text { K: } 5.4 \mathrm{mEq} / \mathrm{dL} \\
\text { Ca. } 1.07 \mathrm{mg} / \mathrm{dL} \\
\text { Lipoprotein a: } 2.2 \mathrm{mg} / \mathrm{dL}\end{array}$ & \\
\hline \multirow[t]{2}{*}{ Microbiological (first wk) } & CMV IgM: 2.2 (Cut-off index $\geq 1.0$ ) & $\begin{array}{l}\text { Anti CMV IgG assay }{ }^{\text {a }} \text { (serum): } 8.4 \mathrm{IU} / \mathrm{mL}(0-5) \\
\text { Anti CMV IgM assay (serum): } 0.2 \mathrm{IU} / \mathrm{mL}(<1) \\
\text { CMV IgG avidity: } 0.0 .83 \text { high avidity }(>0.65)\end{array}$ \\
\hline & $\begin{array}{l}\text { CMV PCR (serum): } 1.77 \times 10^{7} 8 \text { th }^{\mathrm{a}} \\
2.22 \times 10^{4} 12 \text { th } \mathrm{d} \\
3.54 \times 10^{2} 21 \mathrm{st} \mathrm{d} \\
2.31 \times 10^{2} 41 \mathrm{st} \mathrm{d} \\
\text { Toxoplasmosis } \mathrm{IgM} \text { and } \mathrm{IgG} \text { negative } \\
\text { Rubella IgM and IgG negative } \\
\text { Herpes simplex IgM and IgG negative }\end{array}$ & Breast milk PCR: negative \\
\hline Thrombophilia screening (first wk) & Heterozygote mutation MTHFR A1298C & MTHFRA1298C homozygote mutation \\
\hline Direct coombs (at birth) & Negative & \\
\hline Antiphospholipid antibody IgG & Negative & \\
\hline Antiphospholipid antibody lgM & Negative & \\
\hline Anticardiolipin antibody IgG & Negative & \\
\hline Anticardiolipin antibody IgM & Negative & \\
\hline Lupus anticoagulant & Normal & \\
\hline Anti s DNA & Negative & \\
\hline Factors VIII and XI & Negative & \\
\hline Rheumatoid factor & Negative & \\
\hline
\end{tabular}

Abbreviations: ALT, alanine aminotransferase; aPTT, activated partial thromboplastin time; AST, aspartate aminotransferase; BUN, blood urea nitrogen; Ca, calcium; CMV, cytomegalovirus; DNA, deoxyribonucleic acid; IgG, Immunoglobulin G; IgM, Immunoglobulin M; INR, international normalized ratio; K, potassium; Na, sodium; PCR, polymerase chain reaction; PT, Prothrombin time; WBC, white blood cells.

${ }^{a}$ Chemiluminescent microparticle immunoassay.

infected with CMV can pass the virus to the fetus at any time during pregnancy. Moreover, this can happen following a primary infection, reinfection with a different CMV strain or reactivation of a previous infection. This means that unlike rubella, preconceptional immunity to CMV is incomplete and intrauterine transmission and damaging fetal infection can occur in women who are CMV seroimmune prior to pregnancy. ${ }^{7-11}$ More than $90 \%$ of CMV infections during pregnancy are subclinical. ${ }^{8}$ Primary maternal infections are more likely to be transmitted to the fetus and intrauterine transmission occurs in 30 to $40 \%$ of the cases of primary maternal CMV infection..$^{9-11}$ Because no reliable tests can define transmission of infection to the fetus, routine maternal screening for CMV infection during antepartum care is not recommended. However, the critical timing of acute fetal CMV viremia has permitted to diagnose this case. The diagnosis of CMV infection at birth is made by laboratory testing within 2 to 3 weeks of birth by PCR to detect CMV DNA or viral culture to detect the live virus. Testing samples taken from a neonate more than 2 to 3 weeks after birth cannot distinguish between congenital infection and an infection acquired after birth. We herein demonstrated the critical aortic arch thrombosis in the early neonatal life during the full-blown CMV viremia as verified by the presence of a viral DNA load of $1.77 \times 10^{7}$ copies $/ \mathrm{mL}$ in infant's serum. Laboratory indicators of generalized CMV infection in fetal/neonatal blood have been reported as viral DNA load $>3,000$ copies $/ \mathrm{mL}$ and platelet count $<100,000 / \mathrm{mm}^{3,12}$ While fetal viral load $>30,000$ copies $/ \mathrm{mL}$ is also a predictive marker for poor prognosis. Boppana et al reported that no neonates with a viral load $<3,000$ copies/mL developed hearing loss. ${ }^{13} \mathrm{CMV}$ has been reported to infect endothelial cells which enhances thrombin generation. Alternatively, it is 

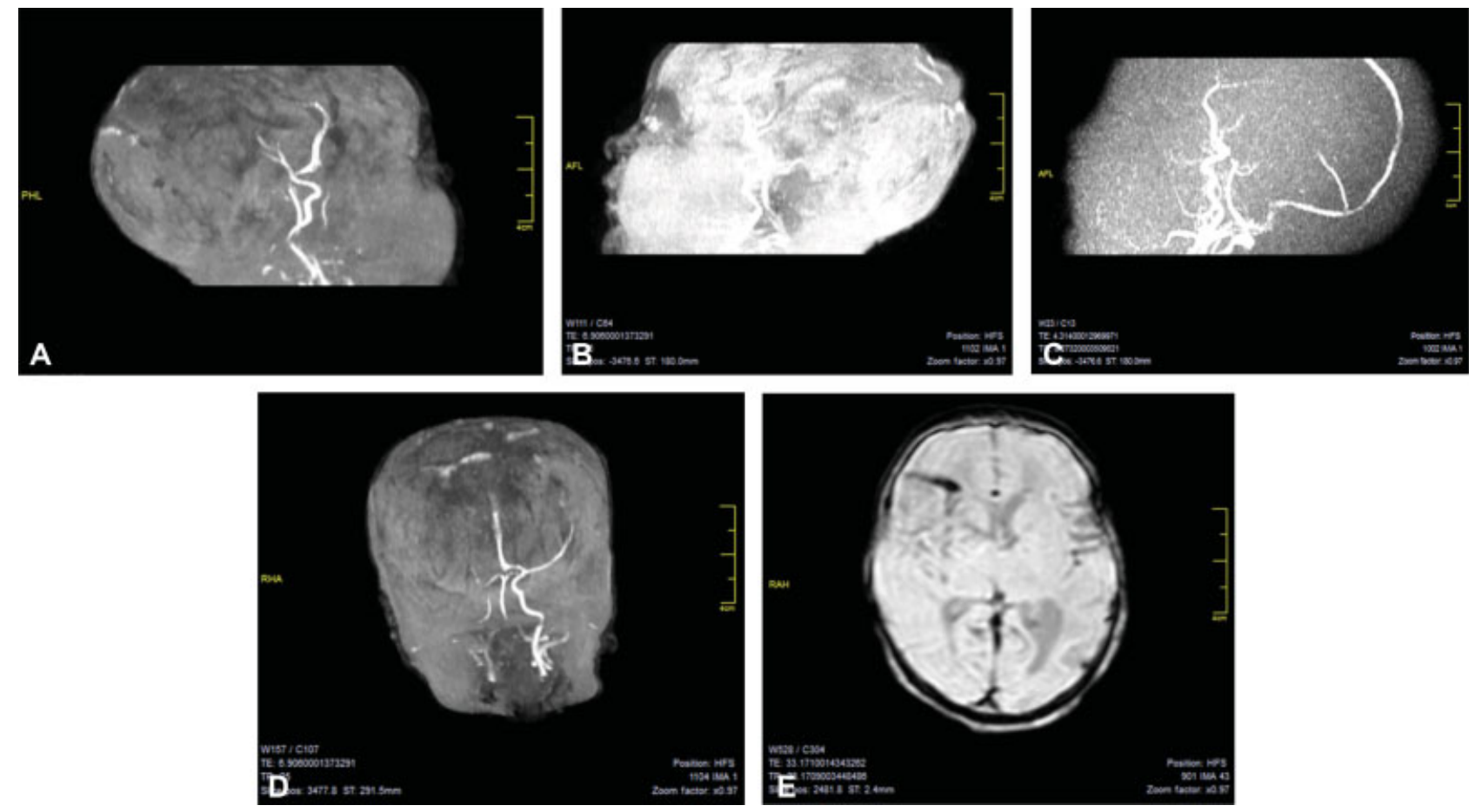

Fig. 1 Magnetic resonance angiography findings of the thrombosis in the aortic arch extending toward the medial lumen of the brachiocephalic trunk with critical occlusion of the left common carotid artery and left subclavian artery. (A) Loss of calibers in the right internal carotid artery. (B) There is no apparent flow in the right thin anterior cerebral artery (C) No apparent flow is seen in the right thin anterior cerebral artery and mid-cerebral artery. (D) Retrograde and collateral circulation, which is thought to be coming from external carotid artery. (E) Swelling of the basal ganglia and leukomalacia. AFL, anterior frontal longitudinal; PHL, posterior hemisphere longitudinal; RHA, right hemisphere anterior.

possible that the number of endothelial binding sites increases, thereby facilitating adhesion of inflammatory cells and platelets. $^{5}$ Besides severe organ failure, CMV infection has been detected more frequently in stillbirths and is associated with fetal thrombotic vasculopathy. ${ }^{14}$ Among the clinical features of adult CMV infection, the incidence of thrombosis among acute CMV infection in hospitalized patients was $6.4 \%$ and the incidence of acute CMV infection among thrombosis hospitalized patients was 1.9 to $9.1 \%{ }^{15}$ Precise diagnosis of fetal tachyarrhythmia and its consequences can be achieved in utero by evaluating hemodynamics with Doppler's ultrasonography on various fetal vessels including the aortic arcus and cerebral arteries. Cost-effectiveness of Doppler's ultrasonography for fetal and neonatal thrombosis and CMV viremia has to be reported.

In conclusion, this case report is an isolated severe thrombotic progress leading to neurologic impairment associated with fetal CMV.

\section{References}

1 Price VE, Chan AKC. Arterial thrombosis in children. Expert Rev Cardiovasc Ther 2008;6(03):419-428

2 Schmidt B, Andrew M. Neonatal thrombosis: report of a prospective Canadian and international registry. Pediatrics 1995;96(5, Pt 1):939-943

3 Nowak-Gottl U. von Kries R, Gobel U. Neonatal symptomatic thromboembolism in Germany: two-year survey. Arch Dis Child Fetal Neonatal Ed 1997;76(03):F163-F167

4 Nagel K, Tuckuviene R, Paes B, Chan AK. Neonatal aortic thrombosis: a comprehensive review. Klin Padiatr 2010;222(03):134-139
5 Sainte S, Suys B, Meyns B, Rega F. Spontaneous aortic arch thrombosis in a neonate. J Thorac Cardiovasc Surg 2013;146(03):e15-e16

6 Lanari M, Lazzarotto T, Papa I, et al. Neonatal aortic arch thrombosis as a result of congenital cytomegalovirus infection. Pediatrics 2001;108(06):E114

7 Cytomegalovirus (CMV) and congenital CMV infection. available from: https://www.cdc.gov/cmv/index.html; accessed on June 5, 2017

8 Ross SA, Fowler KB, Ashrith G, et al. Hearing loss in children with congenital cytomegalovirus infection born to mothers with preexisting immunity. J Pediatr 2006;148(03):332-336

9 Demmler GJ. Infectious Diseases Society of America and Centers for Disease Control. Summary of a workshop on surveillance for congenital cytomegalovirus disease. Rev Infect Dis 1991;13(02): 315-329

10 Fowler KB, Stagno S, Pass RF. Maternal immunity and prevention of congenital cytomegalovirus infection. JAMA 2003;289(08): 1008-1011

11 Stagno S, Pass RF, Cloud G, et al. Primary cytomegalovirus infection in pregnancy. Incidence, transmission to fetus, and clinical outcome. JAMA 1986;256(14):1904-1908

12 Benoist G, Salomon LJ, Jacquemard F, Daffos F, Ville Y. The prognostic value of ultrasound abnormalities and biological parameters in blood of fetuses infected with cytomegalovirus. BJOG 2008;115 (07):823-829

13 Boppana SB, Fowler KB, Pass RF, et al. Congenital cytomegalovirus infection: association between virus burden in infancy and hearing loss. J Pediatr 2005;146(06):817-823

14 Iwasenko JM, Howard J, Arbuckle S, et al. Human cytomegalovirus infection is detected frequently in stillbirths and is associated with fetal thrombotic vasculopathy. J Infect Dis 2011;203(11):1526-1533

15 Justo D, Finn T, Atzmony L, Guy N, Steinvil A. Thrombosis associated with acute cytomegalovirus infection: a meta-analysis. Eur J Intern Med 2011;22(02):195-199 